\title{
Virus-induced gene silencing (VIGS) in cape gooseberry (Physalis peruviana L., Solanaceae)
}

\author{
Jaime A. Osorio-Guarín ${ }^{1}$, Francy L. García-Arias ${ }^{1}$, Roxana Yockteng ${ }^{1,2, *}$
}

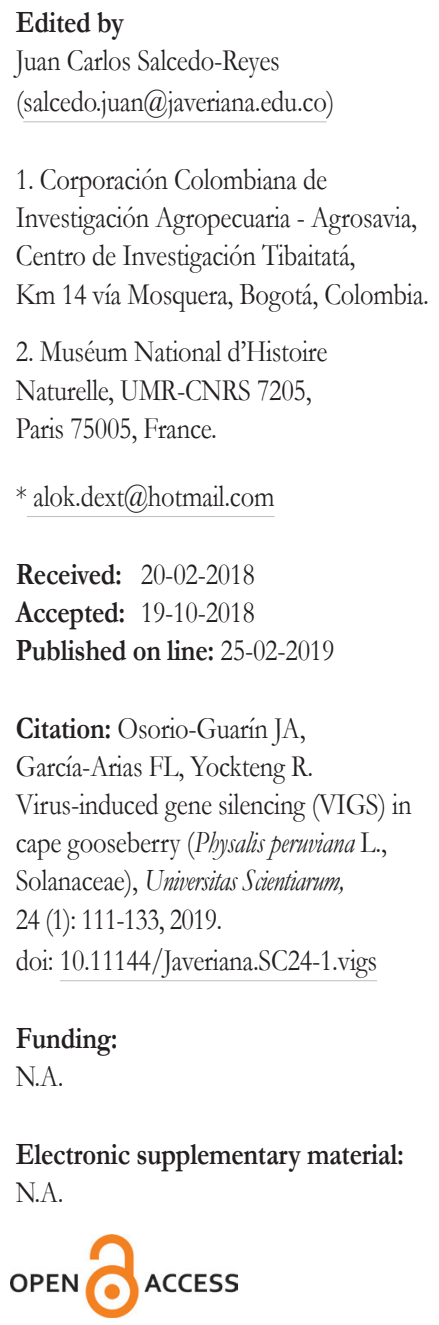

\begin{abstract}
Cape gooseberry (Physalis peruviana, L.) is a herbaceous plant belonging to the Solanaceae family that produces an edible berry appreciated for its nutraceutical and pharmaceutical properties. Its production is often limited by diseases and reproducible fruit quality. Recent studies have reported genes associated with fruit quality and resistance response to the root-infecting fungus Fusarium oxysporum f. sp. physali (Foph,) which causes vascular wilt. In order to standardize a method to validate the biological function of candidate genes in the non-model species $P$. peruviana, we tested the robust approach in reverse genetics, virus-induced gene silencing (VIGS). In this study, we validated and optimized VIGS using an insert of the phytoene desaturase (PDS) gene in a silencing viral vector generated from tobacco rattle virus (TRV). Leaves infiltrated with Agrobacterium (GV3101 strain) showed photo-bleached segments, which were distinctive for $P D S$ suppression at 7 days post-infection (dpi). More than half of the treated plants showed photo-bleaching, indicating an efficiency rate of $50 \%$ of the VIGS protocol. The results of this study showed that VIGS can be used for future functional gene characterization implicated in the immune response, disease resistance and fruit quality in capegooseberry.
\end{abstract}

Keywords: Physalis peruviana; phytoene desaturase; post-transcriptional gene silencing; tobacco rattle virus; virus induced gene silencing.

\section{Introduction}

Cape gooseberry (Physalis peruviana, L.) is an exotic fruit that belongs to the Solanaceae family. It is native to the Andean region and its fruits are recognized by their anti-inflammatory, antioxidant and anticancer properties commonly used to manage diabetes and hypertension [1-3]. Colombia is the world's top producer and exporter with annual sales of $\$ 30$ million 
dollars for 2017 [4, 5]. However, cape gooseberry production is limited due to problems in fruit quality [6] and losses due to the vascular wilt disease [7], caused by the fungus Fusarium oxysporum f. sp. physali (Foph) [8]. In order to understand the molecular mechanisms of important agronomic traits, recent genome wide association studies have been conducted by Osorio-Guarín et al. 2016 [9] and Garcia-Arias et al. 2018 [10] in which 27 and 34 candidate genes were associated to resistance response and fruit quality, respectively.

Despite the high comercial value of cape gooseberry, scarce information regarding gene function is available. Gene function studies are essential to better understand the molecular mechanisms that regulate particular traits generating molecular markers that can assist breeding programs. Consequently, the implementation of techniques for identifying gene functions in P. peruviana is essential.

Techniques such as stable transgene overexpression, DNA transfer, transposon-based mutagenesis and stable RNA interference (RNAi) have been used to analyze the functions of candidate genes [11]. However, these techniques have some disadavantages such as being relatively expensive, time-consuming and laborious [12]. Virus-induced gene silencing (VIGS) is a rapid tool for functional analyses used in different crops and non-model species such as wheat [13], tomato [14] and rye [15]. In addition, this method allows silencing different genes simultaneously in different plant organs like roots and leaves [16-17].

The VIGS technique employs a recombinant virus to specifically reduce endogenous gene activity through a plant defense mechanism called post-transcriptional gene silencing (PTGS) [18]. The binary viral vector used in VIGS contains its viral genome and a fragment of the target gene of the host plant; then the recombinant vector is transferred into the plant via Agrobacterium tumefaciens. Once the virus has spread in the plant, it produces a double-stranded RNAs (dsRNAs) that contains the target gene to be silenced [19]. Dicer-like proteins cleave these viral dsRNAs into short interfering RNAs (siRNA) [20,21]. The siRNA integrates into the RNA-induced silencing complex (RISC) that guides the cleavage of the complementary viral RNA, causing the transiently loss of the gene target function [22].

A commonly used virus in VIGS is the tobacco rattle virus (TRV) [23, 24]. This virus has two genomes: 1) pTRV1, which is essential for the viral movement that causes the infection, and 2) pTRV2, which has genes encoding 
coat and nonstructural proteins; these are not essential for plant infection and are replaced with multiple cloning sites for inserting fragments of the target genes to be silenced [23, 25].

The aim of this study is to optimize the conditions for a TRV-based VIGS protocol and to provide the first gene function screening of Physalis peruviana using the phytoene desaturase (PDS) gene, in which down-regulation shows partial photo-bleaching in green tissues [26].

\section{Materials and methods}

\section{Plant material}

Cape gooseberry (accession 12U134) seeds were obtained from the germplasm collection of Corporación Colombiana de Investigación Agropecuaría (Agrosavia). Forty plants were grown in individual pots with fertilized soil in a greenhouse at $25^{\circ} \mathrm{C}$ under a photoperiodic lighting of $16 \mathrm{~h}$ light/8 h dark.

\section{Primer design}

The coding sequence (CDS) sequence of the PDS gene from tomato (Solanum lycopersicum) was acquired from the National Center for Biotechnology Information NCBI (NM_001247166.2). A BLASTn program was used to compare this gene against the cape gooseberry root/stem transcriptome (NCBI Bioproject ID No. PRJNA67621). The transcript TR18226 aligned with other Solanaceae PDS homologs resulted in the identification of the PpPDS (Physalis peruviana - Phytoene desaturase) sequence; and the best fragment for silencing inside the TR18226 transcript was selected using the VIGS-SGN tool [27].

The primers used to amplify the fragment of the $P p P D S$ gene were designed with the software PRIMER3 v.0.4.0 (http://bioinfo.ut.ee/primer3-0.4.0/) based on a variety of parameters such as primer size of 22 base pairs (bp), primer $\mathrm{Tm}$ of $60^{\circ} \mathrm{C}$, primer $\mathrm{GC} \%$ of 45 . Finally, we added adaptors at the 5'-end of the specific primers to create complementary overlaps useful to anneal the vector and insert [28]. The sequences are: 5'-adaptor: CGACGACAAGACCCT - primer: TGCTTTTGTGTTTGCCACTC-3' and 5'-adaptor: GAGGAGAAGAGCCCT - primer: GGTTCACAACCTGGCACAGT-3’.

\section{PDS amplification}

RNA from young leaves was isolated using the RNeasy Plant Mini Kit (Qiagen, Hilden, Germany). The RNA was treated with the TURBO 
DNase (Ambion) to remove the genomic DNA and transcribed into cDNA using the iScript cDNA Synthesis kit (BioRad) following the manufacturer's instructions. The $P p P D S$ gene was amplified using the cDNA as template with the following parameters: initial denaturation at $95^{\circ} \mathrm{C}$ for $5 \mathrm{~min}, 35$ cycles of $94^{\circ} \mathrm{C}$ for $30 \mathrm{~s}, 57^{\circ} \mathrm{C}$ for $30 \mathrm{~s}$ and $72{ }^{\circ} \mathrm{C}$ for $30 \mathrm{~s}$, followed by a final extension at $72^{\circ} \mathrm{C}$ for $5 \mathrm{~min}$. Finally, the PCR product was purified using the QIAquick PCR Purification Kit (Qiagen) according to the manufacturer's instructions.

\section{Plasmid construction}

Cells containing the pTRV2 (pYL156) and the pTRV1 (pYL192) vectors were grown in liquid $\mathrm{LB}$ medium at $37^{\circ} \mathrm{C}$ overnight at $100 \mathrm{rpm}$, and then plasmid DNA was extracted using the PureLink HQ Mini Plasmid Purification Kit.

The purified $P_{p} P D S$ gene was inserted into the pTRV2 (pYL156) vector from tobacco rattle virus (TRV), previously described by Liu et al. 2002 [29], using the ligation independent cloning (LIC) procedure. In this procedure, the T4 DNA polymerase with exonuclease activity 3' $\rightarrow$ ' removed one of the complementary strands of the adaptor in the vector and in the insert to create overlapping sticky ends.

Five hundred nanograms of the pTRV2 vector (pYL156) were linearized with the PstI enzyme at $37^{\circ} \mathrm{C}$ for $1 \mathrm{~h}$. The linearized product was treated with T4 DNA polymerase (Invitrogen) in $1 \mathrm{x}$ reaction buffer containing $5 \mathrm{mM}$ dTTP at $22{ }^{\circ} \mathrm{C}$ for $30 \mathrm{~min}$, followed by $20 \mathrm{~min}$ of inactivation at $70{ }^{\circ} \mathrm{C}$. In parallel, the same treatment was carried out for the PpPDS product but with $5 \mathrm{mM}$ dATP. Both products were mixed at a 1:1 ratio and incubated for $2 \mathrm{~min}$ at $65^{\circ} \mathrm{C}$, and later for $10 \mathrm{~min}$ at room temperature to allow the annealing of the complementary sticky ends; the final result was the pTRV2:PpPDS vector.

A pTRV2:NobPDS vector with the PDS gene of the species Nicotiana obtusifolia (desert tobacco) constructed by Natalia Pabón-Mora from the EvoDevo research group of the Universidad de Antioquia was used as a positive control. To amplify the Nicotiana $P D S$, the following primers were used: 5'-CGACGACAAGACCCT-CACCTGGGAGTTCCTGTGATAAAT-3' and 5'-GAGGAGAAGAGCCCT-GTGTACAACGCTAATTCAGCG-3'.

\section{Cloning and transformation}

In this phase, six $\mu \mathrm{L}$ of the constructed vector were transformed into $20 \mu \mathrm{L}$ of chemically competent Escherichia coli TOP10 cells. Cells were resuspended in $250 \mu \mathrm{L}$ of S.O.C medium and incubated at $37^{\circ} \mathrm{C}$ for $1 \mathrm{~h}$. Subsequently, $50 \mu \mathrm{L}$ of the transformation mixture was plated onto a LB 
agar plate supplemented with kanamycin $(50 \mu \mathrm{g} / \mathrm{mL})$, and incubated at $37^{\circ} \mathrm{C}$ overnight. Transformants were tested by PCR amplification using $P p P D S$ primers. The PCR product from the $E$. Coli positive transformants were submitted to Sanger sequencing to verify the insert sequence before proceeding with the experiment.

Further, $2 \mu \mathrm{L}$ of the construct was transformed into $50 \mu \mathrm{l}$ of home-made electro-competent Agrobacterium tumefaciens strain GV3101 cells by electroporation using the following program: $2.1 \mathrm{kV}, 100 \Omega$, and $25 \mu \mathrm{F}$ in a MicroPulser (Bio-Rad) electroporator using $0.1 \mathrm{~cm}$ gap electroporation cuvettes. Cells were resuspended in $950 \mu \mathrm{L}$ of S.O.C medium and were then incubated at $28{ }^{\circ} \mathrm{C}$ for $1 \mathrm{~h}$. An aliquot of $70 \mu \mathrm{l}$ of transformation mixture was plated on LB agar supplemented with Kan50, Gent25 and Rif25. The resulting Agrobacterium transformants were grown in liquid $\mathrm{LB}$ medium at $28^{\circ} \mathrm{C}$ during $48 \mathrm{~h}$ at $200 \mathrm{rpm}$; and the plasmid DNA was extracted using the PureLink HQ Mini Plasmid Purification Kit and checked through PCR amplification employing the pTRV2 and PpPDS primers and the products were sequenced by Sanger sequencing. The pTRV1 (pYL192) and pTRV2:NobPDS were transformed in Agrobacterium using the same procedure.

Preparation of virus inoculum and inoculation of cape gooseberry plants

Agrobacterium colonies with the pTRV1, pTRV2:PpPDS and pTRV2:NobPDS vectors were grown separately in $5 \mathrm{~mL}$ of liquid LB medium with Kan50, Gent25, and Rif25, overnight at $28{ }^{\circ} \mathrm{C}$ at $200 \mathrm{rpm}$ in darkness. The cultures were then transferred to $50 \mathrm{~mL}$ of liquid LB medium with Kan50, Gent25, Rif25, $1 \mathrm{M}$ MES, and $0.1 \mathrm{M}$ acetosyringone, and shaken overnight at $200 \mathrm{rpm}$ at $28{ }^{\circ} \mathrm{C}$ in darkness until they reached an optical density $\left(\mathrm{OD}_{600}\right)$ of 1.5. Cells were harvested at $4{ }^{\circ} \mathrm{C}$ at $4000 \mathrm{rpm}$ and resuspended in infiltration medium $\left(1 \mathrm{M} \mathrm{MgCl}_{2}, 1 \mathrm{M} \mathrm{MES}\right.$, and 0.1 $\mathrm{mM}$ acetosyringone) into two different concentrations $\left(\mathrm{OD}_{600}\right.$ of 1.0 and 1.5). Then pTRV1 and pTRV2 were mixed in a 1:1 ratio. The mixtures produced were: 1) pTRV1 and pTRV2:PpPDS at $1.0 \mathrm{OD}, 2) \mathrm{pTRV} 1$ and pTRV2:PpPDS at $1.5 \mathrm{OD}$, and 3) pTRV1 and pTRV2:NoPDS at $1.0 \mathrm{OD}$. Finally, the mixtures were incubated at room temperature for $3 \mathrm{~h}$ before the infiltration process.

Two treatments, two negative controls and one positive control were used during the agroinfiltration step: 1) Five plants were treated with infiltration solution (negative control), 2) Five plants were infiltrated with pTRV1 (negative control), 3) Ten plants were infiltrated with pTRV1-TRV2:PpPDS at OD: $1.0,4)$ Ten plants were infiltrated with pTRV1-pTRV2:PpPDS at 
OD: 1.5, and 5) Ten plants were infiltrated with pTRV1-pTRV2:NobPDS (positive control) at OD: 1.0. Three leaves per plant were infiltrated with a 1 $\mathrm{mL}$ syringe without the needle and then placed in a greenhouse under the following conditions: $16 \mathrm{~h} \mathrm{light} / 8 \mathrm{~h}$ dark cycle, $60 \%$ of relative humidity and a temperature of $25 \pm 2{ }^{\circ} \mathrm{C}$. The experiment was monitored during 47 days post-inoculation (dpi).

Plants with photo-bleaching symptoms were counted during the first 21 dpi. The $P p P D S$ gene-silencing efficiency was calculated as the percentage of plants showing a photo-bleached phenotype in at least one leaf out of the total number of plants tested. In addition, we counted the bleached leaves over the inoculated leaves.

RNA isolation and expression analysis

Small pieces of leaves were frozen in liquid nitrogen and stored at $-80^{\circ} \mathrm{C}$. Total RNA was isolated from mutated and non-mutated leaves from each treatment (OD:1.0, OD:1.5, pTRV1 and infiltration solution) using the RNAeasy Plant Mini Kit (QIAGEN, Germany) according to the manufacturer's instructions, and the final elute was adjusted to $30 \mu \mathrm{L}$. NanoDrop 1000 spectrophotometer (NanoDrop Technologies, Wilmington, DE, U.S.A), was used to quantify the total RNA-DNA. To remove genomic DNA, $10 \mu \mathrm{g}$ of the previous quantification was treated with TURBO DNase (Ambion). For the cDNA synthesis, $500 \mathrm{ng}$ of RNA was used as a template.

Semi-quantitative reverse transcription polymerase chain reaction (RT-PCR) was used to corroborate if the silencing of the PpPDS gene was successful. New primers were designed to prime outside the homology region between the VIGS vector and the previous inserted PDS region. The sequences of the primers were: 5'-TTTACGCAAGTGGCCAAAC-3' and 5'-CCAGGGCAAAAGCAAATAAA-3'. The conditions for the RT-PCR were: initial denaturation at $95^{\circ} \mathrm{C}$ for $5 \mathrm{~min}, 35$ cycles of $94^{\circ} \mathrm{C}$ for $30 \mathrm{~s}$, $57^{\circ} \mathrm{C}$ for $30 \mathrm{~s}$ and $72{ }^{\circ} \mathrm{C}$ for $30 \mathrm{~s}$, followed by a final extension at $72{ }^{\circ} \mathrm{C}$ for 5 $\mathrm{min}$. The reaction was checked through electrophoresis on a $1 \%$ agarose gel.

In addition, real-time quantitative PCR using the $\mathrm{Q}^{\mathrm{TM}} \mathrm{SYBR}^{\circledR}$ Green supermix (BioRad) reagent was conducted in an iQ5 Thermocycler (Bio-Rad) using the $P p P D S$ primers excluding the adaptor sequence at the following conditions: an initial denaturation step of $95^{\circ} \mathrm{C}$ for $3 \mathrm{~min}$, then 40 cycles of $95^{\circ} \mathrm{C}$ for $15 \mathrm{~s}$ followed by $56^{\circ} \mathrm{C}$ for $1 \mathrm{~min}$. Melting curves were generated to check the amplification specificity. The qPCR reaction was carried out using two plants for each of the pTRV1-TRV2:PpPDS treatments. The gene $\alpha$-tubulin was used as endogenous control. 


\section{Results and discussion}

Plant genetic transformation has been used as a robust tool for the genetic engineering of many several crops such as tobacco, tomato, soybean, rice, and wheat. However, transformation protocols in non model species such as $P$. peruviana are less available. In order to validate the function of genes in this species, this study implemented VIGS as a tool for silencing genes in cape gooseberry.

\section{Plasmid construction}

To standardize the VIGS protocol, a PDS gene was used as a target gene because when it is silenced a visible plant phenotype is produced. The non-expression of the PDS gene causes a loss of carotenoids, and as a consequence, plants show the photo-bleached phenotype that has been reported in tomato and tobacco [30]. Liu \& Page (2008) [31] reported that the insert length to silence effectively PDS in Nicotiana benthamiana ranges between $200 \mathrm{bp}$ and $1300 \mathrm{bp}$ and the selected gene region should exclude 3 ' and 5' ends of the PDS gene to be more efficient. The cape gooseberry reference genome is not available, however, we were able to recover the PDS sequence from the available leaf and root transcriptomes (NCBI Bioproject ID No. PRJNA67621).

Using the PDS gene from Solanum lycopersicum as a query against the cape gooseberry leaf transcriptome, a fragment with a length of 2400 bp was detected as the best alignment hit. The VIGS-Tool [27] selected a DNA region between $1600 \mathrm{bp}$ and $2100 \mathrm{bp}$ for this putative PDS gene. The amplified fragment had a size of $440 \mathrm{pb}$ and was inserted in the vector pTRV2 (PYL156). The total size of the vector was 11821 bp (Fig. 1). The fragment



Figure 1. TRV2 vector with the PDS insert. The map was constructed using Geneious software, version 8 . 
sequence was verified by Sanger sequencing and showed a $95 \%$ similarity with 20 bp out of 441 from the S. lycopersicum PDS gene (Fig. 2a). At the protein level, only two amino acid differences out of 147 were found (Fig. 2b), suggesting a highly steady structure of the PDS gene between these two species. The high homology gave us confidence to continue the experiment because several studies have already silenced this gene in tomato $[14,32,33]$.

\section{Gene silencing experiment}

Cai et al. 2006 reported that in Arabidopsis thaliana, the strains C58C1 and LBA4404 were not efficient in silencing the PDS gene. In contrast, the strain GV3101 caused a high efficient silencing in Arabidopsis [24]. TRV vector has been used in many dicot plants to silence genes, and also in several Solanaceous plant species such as tobacco (Nicotiana benthamiana) $[25,30]$ tomato (Solanum lycopersicum) [30], pepper (Capsicum annuum) [34], potato (Solanum tuberosum) [35], and petunia (Petunia bybrida) [36].

Photoperiod and seedling age were tested for $P$. peruviana. At first, we chose plants with two fully expanded cotyledons to infiltrate; however, these plants died after a few days, probably due to a defense mechanism response to Agrobacterium. However, in a new assay using plants with three or four true leaves the PDS gene silencing was successful (Fig. 3).

The PTGS in plants is well known for causing a defense mechanism response against viral infections [21]. As expected, the negative controls did not show signs of photo-bleaching on the leaves (Fig. 3a); but we observed strong viral symptoms such as changes in leaf form and local necrotic lesions for the two treatments with pTRV2:PpPDS (Fig. 3a). The infection did not seem to have affected other morphological characteristics of the plant.



Figure 2. Aligned sequences of PDS gene between cape gooseberry and tomato species. a). DNA sequences, b). Protein sequences. 


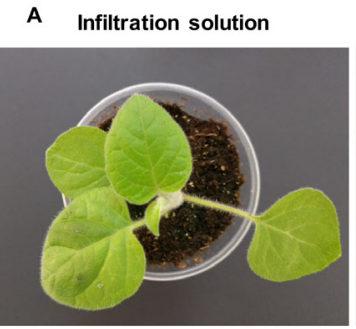

B

Day 0
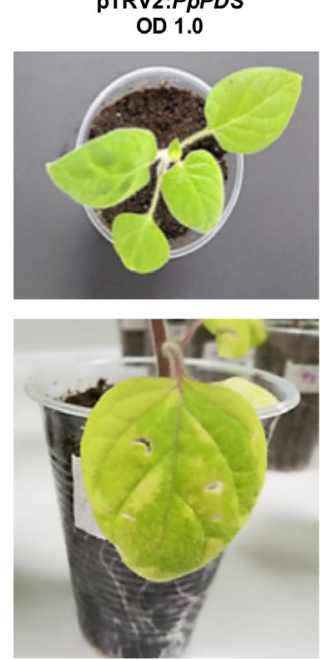

Day 7

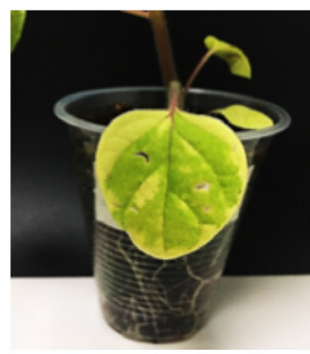

Day 14

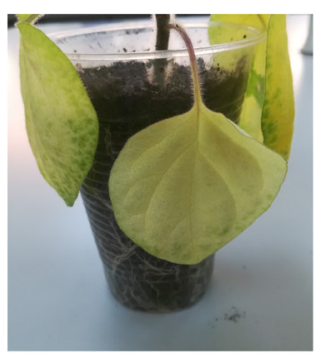

Day 21

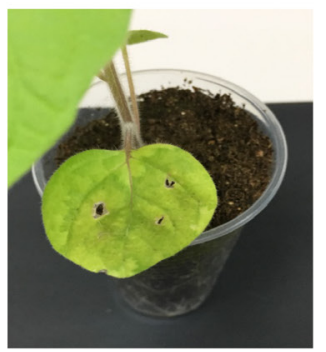

TRV1

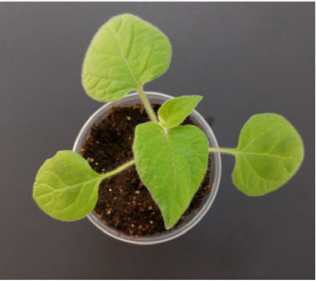

PTRV2:PpPDS

OD 1.5
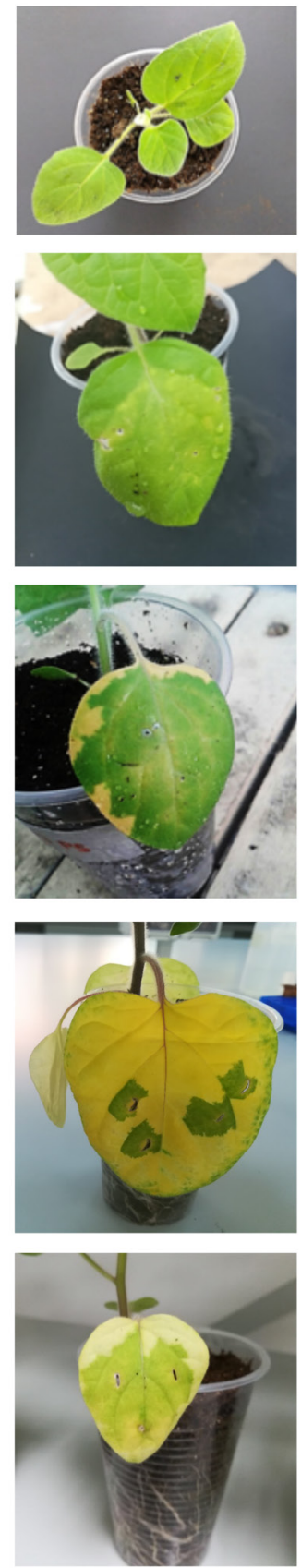

TRV2 OD:1.5



PTRV2:NobPDS

OD 1.0


Figure 3. Images of the effect of VIGS via agro-infiltration of GV3101 strain in plants of $P$. peruviana. a). Control treatments and viral symptoms of GV3101 strains on $\mathrm{OD}=1.0$ and $\mathrm{OD}=1.5$ treatments, $b$ ). Silencing effects of OD:1.0 and OD:1.5 at different days post inoculation. 
Pang et al. 2013 [37] reported $100 \%$ photo-bleaching in Gossypium barbadense, known as extra-long staple cotton, using a photo-period of $16 \mathrm{~h}$ light $/ 8$ h dark, and $92 \%$ using a photo-period of $12 \mathrm{~h}$ light $/ 12 \mathrm{~h}$ dark after two weeks post-inoculation. The appearance of the photo-bleached phenotype is facilitated under high light intensity and long-day photo-period conditions. We previously tested a photoperiod of $12 \mathrm{~h}$ light/12 h dark, in which very small bleach spots across the leaves appeared (data not shown). Despite using $16 \mathrm{~h}$ light $/ 8 \mathrm{~h}$ dark the photo-bleached phenotype emerged in new leaves $7 \mathrm{dpi}$ and occurred for at least 4 weeks. Afterwards, plants began to recover their normal appearance after $28 \mathrm{dpi}$; and the symptoms continued to dissappear until the end of the experiment at $47 \mathrm{dpi}$ (Fig. 3b). The recovering process can be attributed to the transient nature of the VIGS. The photo-bleaching phenotype was also observed with the positive control vector constructed for $N$. obstusifolia. The silenced phenotype was uniformly spread across all the entire leaf in the treatment with OD:1.0 after $21 \mathrm{dpi}$. In treatment with OD:1.5 and with the pTRV2:NobPDS vector, some patchy patterns were observed (Fig. 3b). Similar results in photo-bleaching time and efficiency have been reported in tomato [30], and recently in Solanum rostratum [38], maize and wheat [39].

The PDS silenced plants showed a patchy photo-bleaching pattern, similar to the one reported by Meng et al. 2016 [38]. We observed some variation in gene silencing between plants, probably due to differences in TRV constructs uptake after agro-infiltration. Besides, Kirigia et al. 2014 [40] reported that the translocation of PTGS silencing factor could be affected because of short-range cell-to-cell movements through plasmodesmata and phloem-associated long-range transport mechanisms. Therefore, further studies in cell physiology in cape gooseberry must be conducted to confirm if this can affect the movement of the vector inside the plant. We found that the concentration of $A$. tumefaciens in the culture affects gene silencing; cultures resuspended at OD:1.0 exhibited stronger silencing than OD:1.5 (Fig. 3b). This result is probably due to the thick leaves of cape gooseberry, and therefore, less concentrated inoculum can enter more easily by agro-infiltration with a syringe. To increase the efficiency of the infiltration, vacuum infiltration of a culture with an OD of 0.5 reported in other Solanaceous species was tested $[38,41]$, but no successful silencing effect was observed (data not shown).

From the 20 inoculated plants with the pTRV2:PpPDS vector, 10 plants showed photo-bleaching leaves indicating a rate efficiency of $50 \%$, which is consistent with other reports $[40,42,43]$ (Fig. 4). For each concentration, the efficiency was the same, however, the plants treated with OD:1.5 showed a patchy photo bleaching, meanwhile leaves of plants treated with OD:1.0 

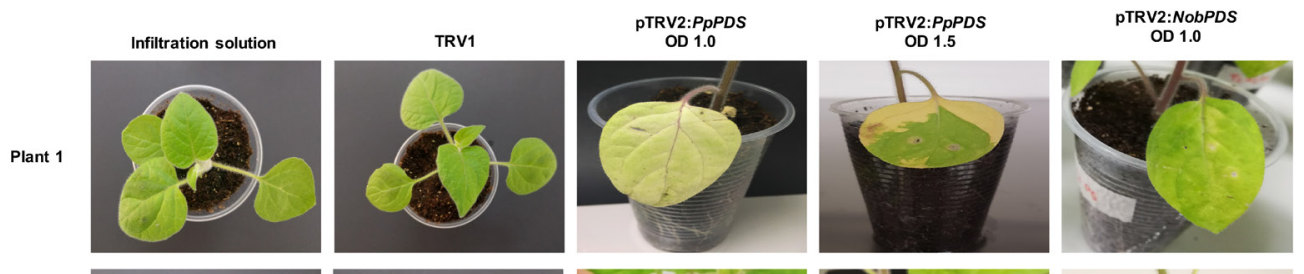

Plant 2
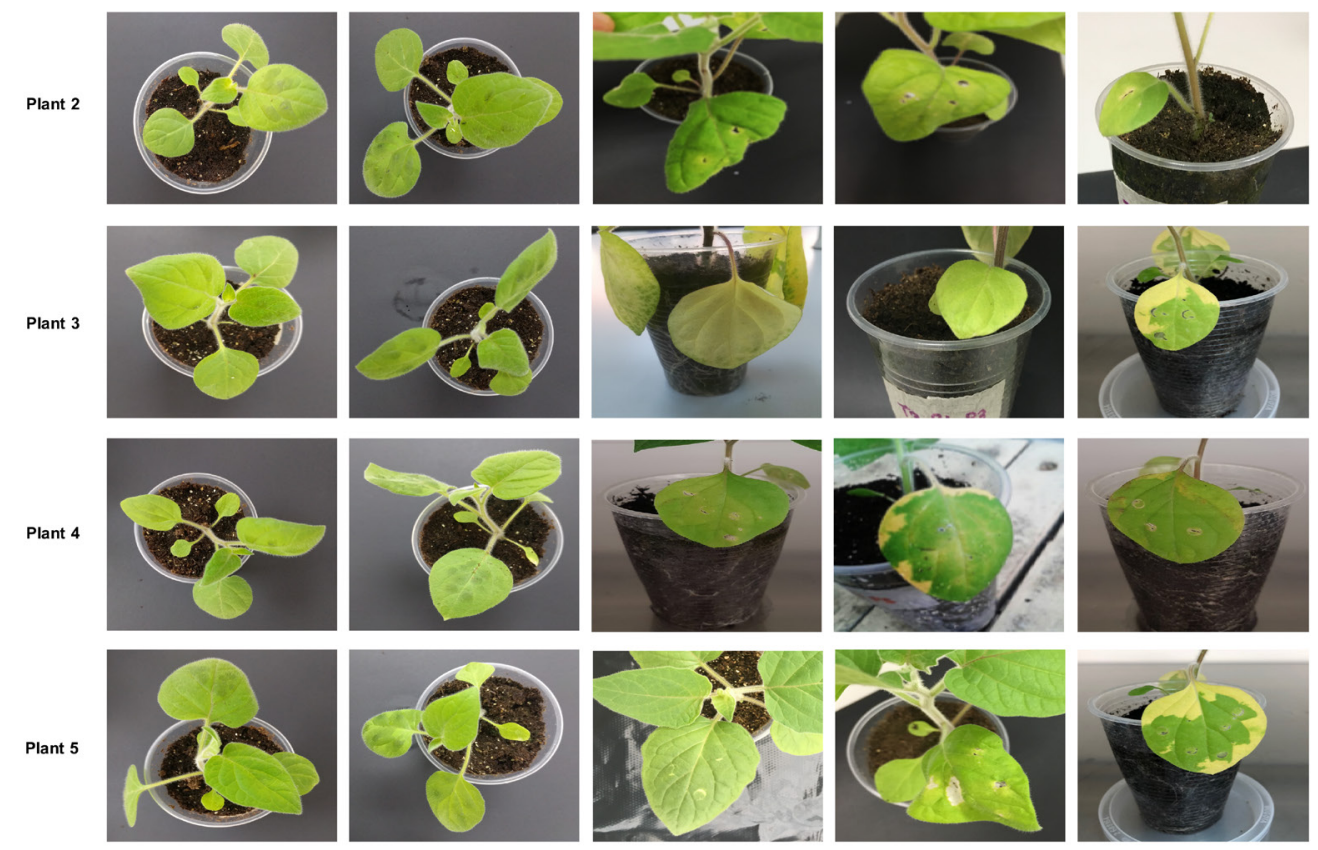

Plant 6
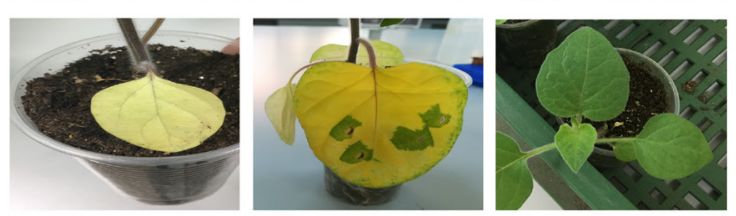

Plant 7
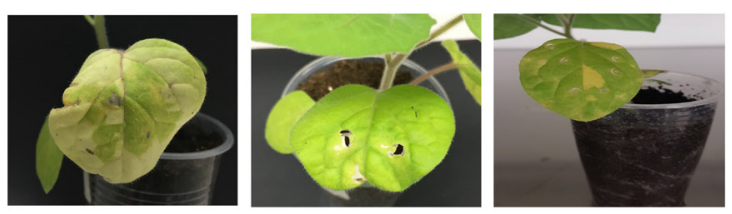

Plant 8
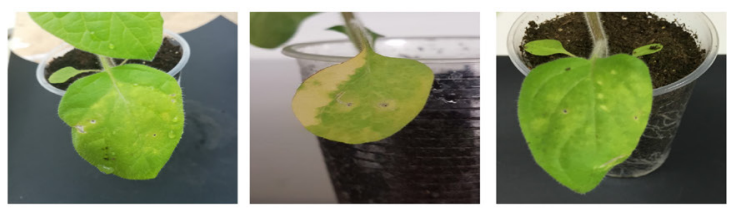

Plant 9
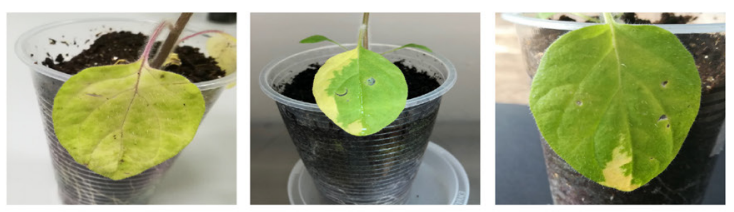

Plant 10


Figure 4. Effects of VIGS in 40 inoculated plants. 
were totally bleached (Fig. 3b). Besides, we observed a higher percentage of bleached leaves in the pTRV2-PpPDS with OD:1.0 compared to the OD:1.5 treatment (47\% and $33 \%$, respectively) (Fig. 5)

It is well known that VIGS efficacy depends on the plant-virus interactions, which can be influenced by environmental factors and the development stage of the plant [23]. In addition, the length of the vector can also affect VIGS [32]. Further work to test the influence of the environment and length of the insert in VIGS of cape gooseberry may be necessary. It is also critical to assess different plant developmental stages as we mentioned above.

\section{RT-PCR and qPCR analysis}

The abundance of $P p P D S$ transcript levels through semi-quantitative RT-PCR was confirmed using primers that annealed outside the targeted region for gene silencing and near the untranslated region (UTR) of the PDS gene. These primers were specifically designed to anneal the plant gene in order to avoid the amplification of the pTRV2:PpPDS construct. As expected, these primers weakly amplified a $176 \mathrm{bp}$ fragment, indicating a low expression of the PDS gene in treated plants (Line 3 and 4) (Fig. 6). In contrast, PDS was highly expressed in control plants (Line 1 and 2), in which no down-regulation was expected (Fig. 6). The amplification of the constitutive gene $\alpha$-tubulin gave a $133 \mathrm{bp}$ fragment, corresponding to the expected size in all samples.

The relative transcript abundance of the PpPDS gene estimated by qPCR was also significantly higher in infiltration solution and pTRV1 treatments than in plants inoculated with the pTRV2:PpPDS construct at different OD

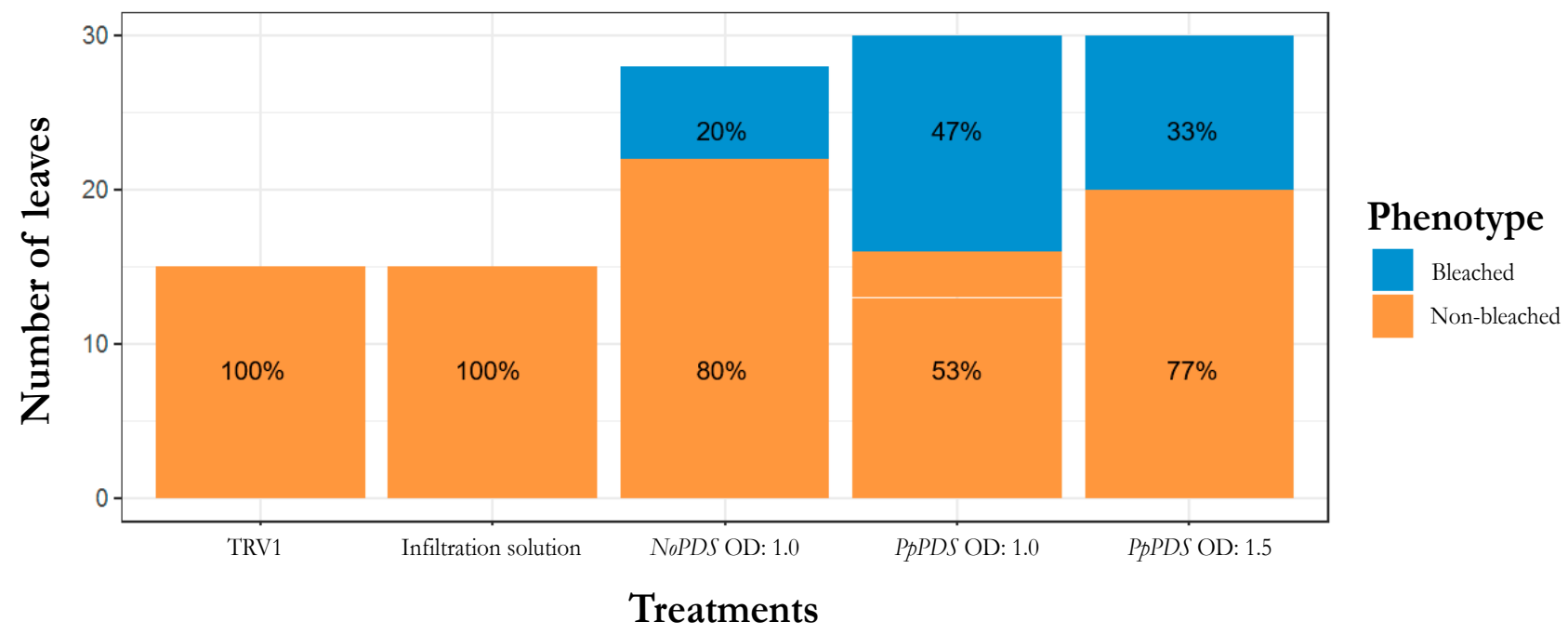

Figure 5. Comparison between the number of bleached and non-bleached leaves. 




Figure 6. Expression of PDS and $\alpha$-tubulin by semiquantitative RT-PCR. Lane 1 corresponds to leaf tissue inoculated with infiltration solution, lane 2 corresponds to pTRV1, lane 3 corresponds to pTRV2:PpPDS OD:1.0, lane 4 corresponds to pTRV2:PpPDS OD:1.5. $\alpha$-tubulin was selected as an endogenous control.

concentrations (Fig. 7). As expected, the gene was less expressed in plants with OD:1.0 treatment compared to plants with OD:1.5 treatment, corroborating the phenotypic characterization. As explained earlier, the infiltration process is facilitated with lower ODs. The reduction in pTRV2:PpPDS transcripts in infected plants with OD:1.0 and OD:1.5 was $88 \%$ and $47.5 \%$ respectively, compared to control plants. Hence, the inoculum concentration has a significant influence on the VIGS effectiveness. In addition, the melting curves showed a specific amplification of the PDS and $\alpha$-tubulin showing two separate peaks with sequence specific shapes at the dissociation curve. 


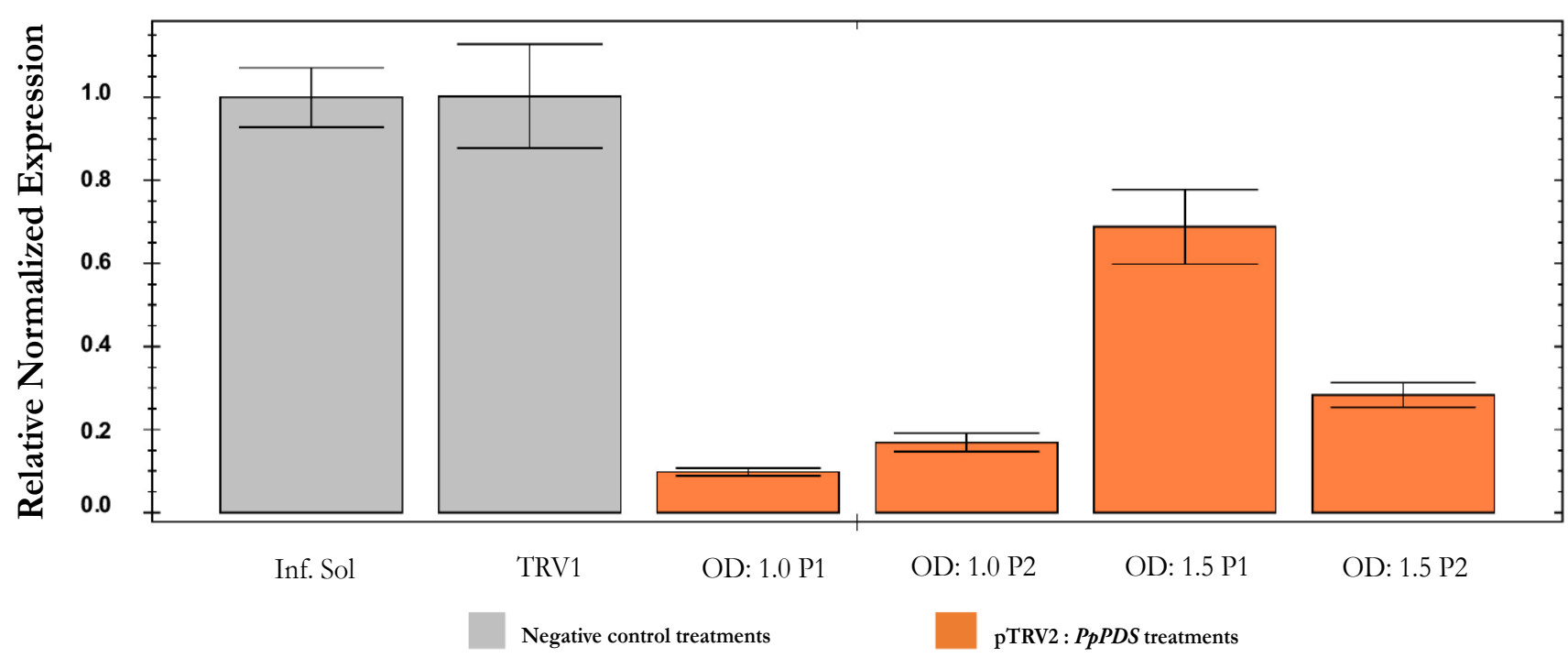

Figure 7. Results of the qPCR of the PDS gene in P. perwviana. $\alpha$-tubulin was used to normalize the expression of the PDS gene.

\section{Conclusions}

In this study, we established a TRV-based VIGS system that can successfully induce photo-bleaching by silencing the PDS gene in cape gooseberry leaves. Using the Agrobacterium strain GV3101 with an OD of 1.0 and the leaf syringe-infiltration method, silencing efficiency can reach to approximately $50 \%$. These results constitute the first functional gene study in $P$. peruviana showing that VIGS using TRV can be effectively used in the future to corroborate the function of candidate genes related to important agronomic traits such as resistance response and fruit quality.

\section{Acknowledgments}

The TRV silencing vectors used in this study were provided by Dr. S. P. Dinesh-Kumar. We want to thank Edgar Jimenez for having supplied seed plant material for the analyses. Moreover, we want to thank Natalia Pabón-Mora and Clara Ortiz for having provided the pTRV2:NobPDS vector and their assessment during the study. In addition, we thank Linda Gómez-Arias and Dora Janeth Garcia by their help provided to develop the experiments.

\section{Conflict of interest}

The autors declare they have no competing interests. 


\section{References}

[1] Jin Z, Mashuta M, Stolowich N, Vaisberg A, Stivers N, Bates P, Lewis W, Hammond G. Physangulidines A, B, and C: Three New Antiproliferative Withanolides from Physalis angulata L., Organic Letters, 14 (5): 1230-1233, 2012.

doi: 10.1021/ol203498a

[2] Ramadan MF. Bioactive phytochemicals, nutritional value, and functional properties of cape gooseberry (Physalis peruviana): An overview, Food Research International, 44 (7): 1830-36, Aug. 2011.

doi: 10.1016/j.foodres.2010.12.042

[3] Ramadan M, El-Ghorab A, Ghanem K. Volatile compounds, antioxidants, and anticancer activities of Cape gooseberry fruit (Physalis peruviana L.): An in-vitro study, Journal of The Arab Society for Medical Research, 10 (2): 56, 2015.

doi: $10.4103 / 1687-4293.175556$

[4] Menzel MY. The Cytotaxonomy and Genetics of Physalis, Proceedings of the American Philosophical Society, 95 (2): 132-183, 1951. https://www.jstor.org/stable/3143331

[5] Popenoe H, King S, León J, Kalinowski L. Goldenberry (Cape Gooseberry), in Lost Crops of the Incas, H. Popenoe, S. King, J. León, and L. Kalinowski, Eds. Washington, USA, National Academy Press, 1989, 415.

[6] Valdenegro M, Almonacid S, Henríquez C, Lutz M, Fuentes L, Simpson R. Effects of drying processes on organoleptic characteristics and the health quality of food ingredients obtained from goldenberry fruits (Physalis peruviana), Open Access Scientific Reports, 2: 642, 2013.

https://www.omicsonline.org/scientific-reports/srep642.php

[7] González C, Barrero LS. Estudio de la marchitez vascular de la uchuva para el mejoramiento genético del cultivo. Bogotá, Colombia, Editorial Kimpress, 2011.

[8] Simbaqueba J, Catanzariti A, González C, Jones D. Evidence for horizontal gene transfer and separation of effector recognition from effector function revealed by analysis of effector genes shared between cape-gooseberry- and tomato-infecting formae speciales of Fusarium oxysporum, Molecular Plant Pathology, 22: 2017.

doi: $10.1111 / \mathrm{mpp} .12700$ 
[9] Osorio-Guarín JA, Enciso-Rodríguez FE, González C, FernándezPozo N, Mueller LA, Barrero LS. Association analysis for disease resistance to Fusarium oxysporum in cape gooseberry (Physalis peruviana L), BMC Genomics, 17 (1): 248, 2016.

doi: 10.1186/s12864-016-2568-7

[10] García-Arias FL, Osorio-Guarín JA, Núñez Zarantes VM. Association Study Reveals Novel Genes Related to Yield and Quality of Fruit in Cape Gooseberry (Physalis peruviana L.), Frontiers in Plant Science, 9:362, 2018.

doi: 10.3389/fpls.2018.00362

[11] Lee WS, Rudd JJ, Kanyuka K. Virus induced gene silencing (VIGS) for functional analysis of wheat genes involved in Zymoseptoria tritici susceptibility and resistance, Fungal Genetics and Biology, 79: 84-88, 2015.

doi: 10.1016/j.fgb.2015.04.006

[12] Burch-Smith TM, Anderson JC, Martin GB, Dinesh-Kumar SP. Applications and advantages of virus-induced gene silencing for gene function studies in plants, The Plant Journal, 39 (5): 734-746, 2004.

doi: 10.1111/j.1365-313X.2004.02158.x

[13] Zhang N, Huo W, Zhang L, Chen F, Cui D. Identification of Winter-Responsive Proteins in Bread Wheat Using Proteomics Analysis and Virus-Induced Gene Silencing (VIGS), Molecular \& Cellular Proteomics, 15 (9): 2954-2969, 2016.

doi: 10.1074/mcp.M115.057232

[14] Fantini E, Giuliano G. Virus-Induced Gene Silencing as a Tool to Study Tomato Fruit Biochemistry, in Plant Signal Transduction: Methods and Protocols, J. R. Botella and M. A. Botella, Eds. New York, NY, Springer New York, 65-78, 2016.

doi: 10.1007/978-1-4939-3115-6_7

[15] Groszyk J, Kowalczyk M, Yanushevska Y, Stochmal A, RakoczyTrojanowska M, Orczyk W. Identification and VIGS-based characterization of $B \times 1$ ortholog in rye (Secale cereale L.), PLOS ONE, 12 (2): e0171506, 2017.

doi: 10.1371/journal.pone.0171506

[16] Kawalek A, Dmochowska-Boguta M, Nadolska-Orczyk A, Orczyk W. A new BSMV-based vector with modified $\beta$ molecule allows simultaneous and stable silencing of two genes, Cellular \& molecular biology letters, 17 (1): 107-23, 2012.

doi: 10.2478/s11658-011-0041-9 
[17] Bennypaul HS, Mutti JS, Rustgi S, Kumar N, Okubara PA, Gill KS. Virus-induced gene silencing (VIGS) of genes expressed in root, leaf, and meiotic tissues of wheat, Functional \& Integrative Genomics, 12 (1): 143-156, 2012.

doi: 10.1007/s10142-011-0245-0

[18] Voinnet O. RNA silencing as a plant immune system against viruses, Trends in Genetics, 17 (8): 449-459, 2001.

doi: 10.1016/S0168-9525(01)02367-8

[19] Donaire L, Wang Y, Gonzalez-Ibeas D, Mayer KF, Aranda MA, Llave C. Deep-sequencing of plant viral small RNAs reveals effective and widespread targeting of viral genomes, Virology, 392 (2): 203-214, 2009.

doi: 10.1016/j.virol.2009.07.005

[20] Ding S-W, Voinnet O. Antiviral Immunity Directed by Small RNAs, Cell, 130 (3): 413-426, 2007.

doi: 10.1016/j.cell.2007.07.039

[21] Baulcombe D. RNA silencing in plants, Nature, 431 (7006): 356363, Sep. 2004.

doi: $10.1038 /$ nature02874

[22] Lange M, Yellina AL, Orashakova S, Becker A. Virus-Induced Gene Silencing (VIGS) in Plants: An Overview of Target Species and the Virus-Derived Vector Systems, , in Virus-Induced Gene Silencing: Methods and Protocols, A. Becker, Ed. Totowa, NJ, Humana Press, 2013, 1-14.

doi: 10.1007/978-1-62703-278-0_1

[23] Senthil-Kumar M, Mysore KS. Tobacco rattle virus-based virusinduced gene silencing in Nicotiana benthamiana, Nature Protocols, 9 (7): 1549-1562, 2014.

doi: $10.1038 /$ nprot.2014.092

[24] Cai X-Z, Xu Q-F, Wang C-C, Zheng Z. Development of a VirusInduced Gene-Silencing System for Functional Analysis of the RPS2-Dependent Resistance Signalling Pathways in Arabidopsis, Plant Molecular Biology, 62 (1-2): 223-232, 2006.

doi: 10.1007/s11103-006-9016-z 
[25] Ratcliff F, Martin-Hernandez AM, Baulcombe DC. Technical Advance: Tobacco rattle virus as a vector for analysis of gene function by silencing, The Plant Journal, 25 (2): 237-245, 2001.

doi: 10.1046/j.0960-7412.2000.00942.x

[26] Kumagai MH, Donson J, della-Cioppa G, Harvey D, Hanley K, Grill LK. Cytoplasmic inhibition of carotenoid biosynthesis with virus-derived RNA, Proceedings of the National Academy of Sciences of the United States of America, 92 (5): 1679-1683, 1995.

[27] Fernandez-Pozo N, Rosli HG, Martin GB, Mueller LA. The SGN VIGS Tool: User-Friendly Software to Design Virus-Induced Gene Silencing (VIGS) Constructs for Functional Genomics, Molecular Plant, 8 (3): 486-488, 2015.

doi: 10.1016/j.molp.2014.11.024

[28] Dong Y, Burch-Smith TM, Liu Y, Mamillapalli P, Dinesh-Kumar SP. A Ligation-Independent Cloning Tobacco Rattle Virus Vector for High-Throughput Virus-Induced Gene Silencing Identifies Roles for NbMADS4-1 and -2 in Floral Development, Plant Physiology, 145 (4): 1161-1170, 2007.

doi: 10.1104/pp.107.107391

[29] Liu Y, Schiff M, Marathe R, Dinesh-Kumar SP. Tobacco Rar1, EDS1 and NPR1/NIM1 like genes are required for N-mediated resistance to tobacco mosaic virus, The Plant Journal, 30 (4): 415429, 2002.

doi: 10.1046/j.1365-313X.2002.01297.x

[30] Liu Y, Schiff M, Dinesh-Kumar SP. Virus-induced gene silencing in tomato, The Plant Journal, 31 (6): 777-786, 2002.

doi: 10.1046/j.1365-313X.2002.01394.x

[31] Liu E, Page JE. Optimized cDNA libraries for virus-induced gene silencing (VIGS) using tobacco rattle virus, Plant Methods, 4 (1): 5, 2008 .

doi: 10.1186/1746-4811-4-5

[32] Velásquez AC, Chakravarthy S, Martin GB. Virus-induced Gene Silencing (VIGS) in Nicotiana benthamiana and Tomato, Journal of Visualized Experiments JoVE, (28): 1292, 2009.

doi: $10.3791 / 1292$ 
[33] Romero I, Tikunov Y, Bovy A. Virus-induced gene silencing in detached tomatoes and biochemical effects of phytoene desaturase gene silencing, Journal of Plant Physiology, 168 (10): 1129-1135, 2011.

doi: 10.1016/j.jplph.2010.12.020

[34] Chung E, Seong E, Kim Y-C, Chung EJ, Oh S-K, Lee S, Park JM, Joung YH, Choi D. A Method of High Frequency Virusinduced Gene Silencing in Chili Pepper (Capsicum annuum L. cv. Bukang), Mol. Cells, 17 (2): 377-380, 2004.

[35] Brigneti G, Martín-Hernández AM, Jin H, Chen J, Baulcombe DC, Baker B, Jones JDG. Virus-induced gene silencing in Solanum species, The Plant Journal, 39 (2): 264-272, 2004.

doi: 10.1111/j.1365-313X.2004.02122.x

[36] Chen J-C, Jiang C-Z, Reid MS. Silencing a prohibitin alters plant development and senescence, The Plant Journal, 44 (1): 16-24, 2005. doi: 10.1111/j.1365-313X.2005.02505.x

[37] Pang J, Zhu Y, Li Q, Liu J, Tian Y, Liu Y, Wu J. Development of Agrobacterium-Mediated Virus-Induced Gene Silencing and Performance Evaluation of Four Marker Genes in Gossypium barbadense, PLOS ONE, 8 (9): e73211, 2013.

doi: 10.1371/journal.pone.0073211

[38] Meng L-H, Wang R-H, Zhu B-Z, Zhu H-L, Luo Y-B, Fu D-Q. Efficient Virus-Induced Gene Silencing in Solanum rostratum, PLOS ONE, 11 (6): e0156228, 2016.

doi: 10.1371/journal.pone.0156228

[39] Zhang J, Yu D, Zhang Y, Liu K, Xu K, Zhang F, Wang J, Tan G, Nie X, Ji Q, Zhao L, Li C. Vacuum and Co-cultivation Agroinfiltration of (Germinated) Seeds Results in Tobacco Rattle Virus (TRV) Mediated Whole-Plant Virus-Induced Gene Silencing (VIGS) in Wheat and Maize, Frontiers in Plant Science, 8: 1-12, 2017.

doi: $10.3389 /$ fpls.2017.00393

[40] Kirigia D, Runo S, Alakonya A. A virus-induced gene silencing (VIGS) system for functional genomics in the parasitic plant Striga hermonthica, Plant Methods, 10 (1): 16, 2014.

doi: 10.1186/1746-4811-10-16 
[41] Yan H, Fu D, Zhu B, Liu H, Shen X, Luo Y. Sprout vacuuminfiltration: a simple and efficient agroinoculation method for virus-induced gene silencing in diverse solanaceous species, Plant Cell Reports, 31 (9): 1713-1722, 2012.

doi: 10.1007/s00299-012-1285-1

[42] Xu H, Xu L, Yang P, Cao Y, Tang Y, He G, Yuan S, Ming J. Tobacco rattle virus-induced Phytoene desaturase (PDS) and $\mathrm{Mg}$-chelatase $\mathrm{H}$ subunit $(\mathrm{ChlH})$ gene silencing in Solanum pseudocapsicum L., PeerJ, 6 e4424, 2018.

doi: $10.7717 /$ peerj.4424

[43] Wang T, Wen L, Zhu H. Effectively organ-specific virus induced gene silencing in tomato plant, Journal of Nature and Science (JNSCI), 1 (1): 34, 2015. 


\section{Silenciamiento génico inducido por virus (VIGS) en uchuva (Physalis peruviana L., Solanaceae)}

Resumen: La uchuva (Physalis peruviana, L.) es una planta herbácea perteneciente a la familia de las solanáceas, que produce una baya comestible apreciada por sus propiedades nutracéuticas y farmacéuticas. Su producción con frecuencia se ve limitada debido a enfermedades y a falta de reproducibilidad en la calidad del fruto. Estudios recientes han reportado genes asociados con la calidad del fruto y con la respuesta de resistencia al hongo radicular Fusarium oxysporum f. sp. physali (Foph,), que causa marchitamiento vascular. Con el fin de estandarizar un método para validar la función biológica de genes candidatos en la especie no-modelo $P$. peruviana, evaluamos la aproximación robusta en genética inversa, el silenciamiento génico inducido por virus (VIGS). En este estudio, validamos y optimizamos el VIGS usando un inserto de la fitoeno desaturasa (PDS) en un vector viral de silenciamiento producido a partir del virus del cascabeleo del tabaco (TRV). Las hojas infiltradas con Agrobacterium (cepa GV3101) mostraron segmentos fotoblanqueados, que fueron distintivos para la supresión de PDS a 7 días pos-infeccion (dpi). Más de la mitad de las plantas tratadas mostraron fotoblanqueo, lo cual indica una tasa de eficiencia del $50 \%$ del protocolo VIGS. Los resultados de este estudio mostraron que el VIGS se puede usar en futuras caracterizaciones de genes funcionales implicados en la respuesta inmune, la resistencia a enfermedad y la calidad del fruto en la uchuva.

Palabras clave: Physalis peruviana; fitoeno desaturasa; silenciamiento post-transcripcional de genes; virus del cascabeleo del tabaco; silenciamiento de genes inducido por virus. 


\section{Silenciamento de genes induzidos por vírus (VIGS) em physalis (Physalis peruviana L., Solanaceae)}

Resumo: A physalis (Physalis peruviana, L.) é uma planta herbácea pertencente à família Solanaceae, que produz uma baga comestível apreciada por suas propriedades nutracêuticas e farmacêuticas. Sua produção com frequência se vê limitada devido a enfermidades e baixa reprodutibilidade na qualidade do fruto. Estudos recentes reportaram genes associados com a qualidade do fruto e com a resposta de resistência ao fungo radicular Fusarium oxysporum f. sp. physali (Foph.), que causa esmorecimento vascular. Com a finalidade de padronizar um método para validar a função biológica de genes candidatos na espécie não-modelo P. p ruviana, avaliamos uma aproximação robusta em genética invertida, o sil nciamento de genes induzidos por vírus (VIGS). Neste estudo, validamos e otimizamos o VIGS usando um inserto da fitoeno desaturase (PDS) em um vetor viral de silenciamento produzido a partir do vírus do chocalho do tabaco (TRV). As folhas infiltradas com Agrobacterium (cepa GV3101) mostraram segmentos fotobranqueados, que foram distintivos para a supressão de PDS a 7 dias pós-infecção (dpi). Mais da metade das plantas tratadas mostraram fotobranqueamento, o que indica uma taxa de eficiência de $50 \%$ do procotolo VIGS. Os resultados de este estudo mostraram que o VIGS pode ser usado em caracterizações futuras de genes funcionais implicados na resposta imune, na resistência a enfermidades e na qualidade do fruto de physalis.

Palavras-chave: Physalis peruviana; fitoeno desaturase; silenciamento pós-trasncriptacional de genes; vírus do chocalho do tabaco; silenciamento de genes induzidos por vírus. 


\section{Jaime Andrés Osorio Guarín}

Biologist graduated from Pontificia Universidad Javeriana and Master in Agricultural Sciences from Universidad Nacional de Colombia. Qualified in fundamental or applied research in various areas of biology such as molecular biology, plant breeding and genetics and basic management of bioinformatic algorithms, with the aim of characterizing collections of plant species, identification and functional validation of genes associated with characteristics of agronomic interest.

ORCID: 0000-0002-5486-2680

\section{Francy Liliana García-Arias}

Biologist graduated from Universidad Pedagógica y Tecnológica de Colombia - UPTC and Master's degree in Agricultural Science at Universidad Nacional de Colombia - UNAL. Researcher of Agrosavia focusing in molecular biology and plant breeding studies, including the mapping of candidate genes related to fruit quality and the polyploidization of haploid plants in cape gooseberry.

ORCID: 0000-0003-3112-9950

\section{Roxana Yockteng}

Biologist graduated from Universidad de los Andes with a Master's degree in Biology with emphasis in Population Genetics and a $\mathrm{PhD}$ in Evolutionary Biology from the University Paris XI, in France. Associate Professor of the MNHN in Paris, and since 2014 is an associate $\mathrm{PhD}$ researcher at Agrosavia, studying the genetics behind important agronomic traits in crop species.

ORCID: 0000-0003-2133-6139 